\title{
STRESS ANALYSIS OF DENTAL IMPLANT INSERTED IN THE MANDIBLE
}

\author{
LAGODA Agnieszka ${ }^{1}$, NIESLONY Adam ${ }^{2}$ \\ ${ }^{1}$ Faculty of Mechanical Engineering, Opole University of Technology, Department of Mechanics and Machine \\ Design, Mikotajczyka 5, 45-270 Opole, Poland, a.materac@po.opole.pl \\ ${ }^{2}$ Faculty of Mechanical Engineering, Opole University of Technology, Department of Mechanics and Machine \\ Design, Mikołajczyka 5, 45-270 Opole, Poland, a.nieslony@po.opole.pl
}

\begin{abstract}
The aim of the paper is to obtain the values of dental implant stress analysis. The dental implant was inserted in the part of mandible bone. Stress analysis was carried out using the Finite Elements Method and simplified models.
\end{abstract}

KEYWORDS: Dental implant, stress analysis, mandible, bone

\section{Introduction}

Dental implantology is one of the fastest developing method of replacing the teeth lose. Successful treatment effect is very satisfactory and mimics natural teeth. The esthetics is the main reason why people more and more often choose implants instead of other methods [1]. When number of implant surgeries increased, dentists started to consider the biological implant treatment aspects. First person who wrote scientific paper about osseointegration process was Brånemark [2]. Osseointegration is a integration process between human bone and the titanium implant screw. After this discover, scientists began the complex and detailed research. Dental implant manufacturers initiated the mechanical aspects research in their implant systems [3].

It's very difficult to estimate the behavior of bone and dental implant, despite the fact there exist few experimental methods [4]. Implant made from titanium alloy is screwed directly into the bone and after 3-6 months of healing is ready to become a holder for the abutment and the artificial crown. The stability of dental implant is connected to several conditions. First of them is the patient's bite force. It generates the load on every part of dental implant system and bone. Assuming that the osseointegration process is correct, computer simulations help predict the implant construction behavior and assess the stress and displacements values before the surgery. The use of Finite Elements Method might allow the dentists to carry out the preclinical stress analysis of every implant system component with the bone and estimate the level of dental implant treatment success.

\section{Methodology}

The simplified model prepared for FEM analysis was based on real CAMLOG ${ }^{\circledR}$ two-fazed dental implant system and consists of few elements: 1 - none threaded implant, 2 - abutment, 3 - connection screw. Number 4 and 5 was respectively for spongy bone and cortical bone (fig. $1)$. 

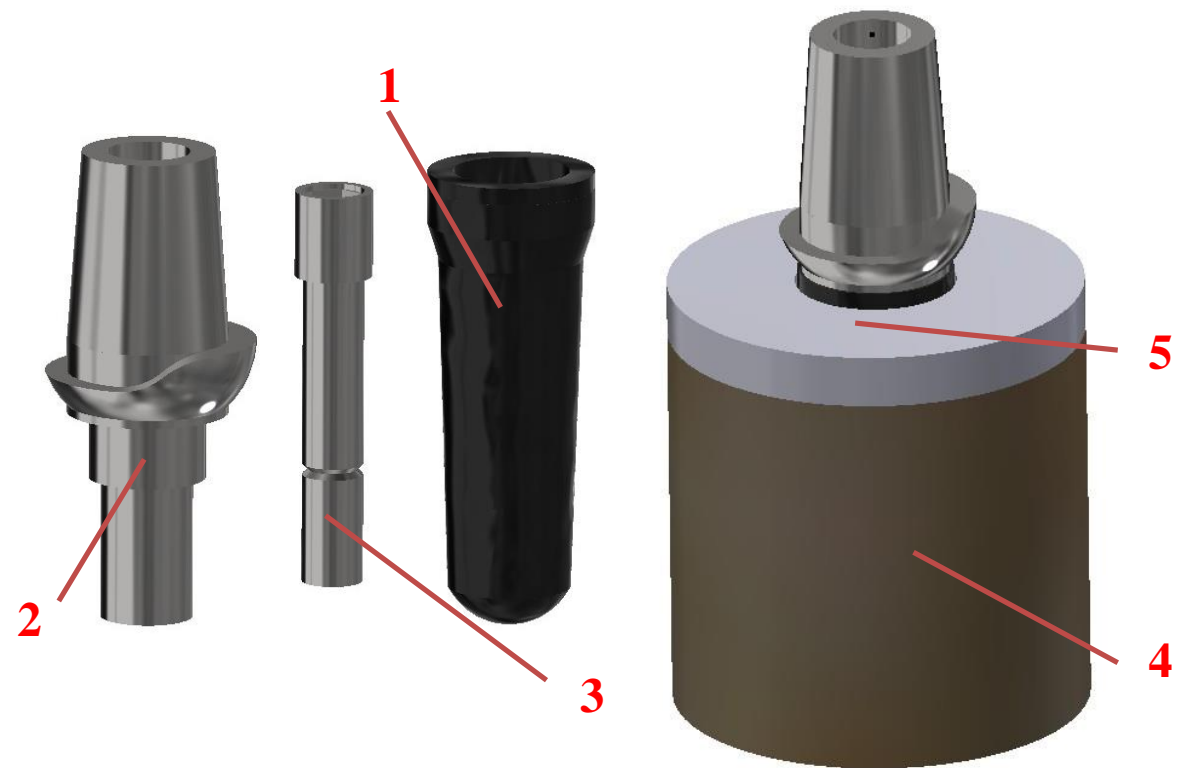

Fig. 1 Simplified models for FEM analysis, where: 1 - implant, 2 - abutment, 3 - connection screw, 4 - spongy bone, 5 - cortical bone

The implant screw diameter was $\varnothing 6$ and its length was $1=16 \mathrm{~mm}$. The cortical bone layer thickness was $2 \mathrm{~mm}$. To ensure the right effect of mandible bone behavior on the dental implant, both of modeled bone structures got different material properties. The cortical bone is orthotropic kind of material, where $\mathrm{X}$ is for axial direction, $\mathrm{Y}$ for mesiodistal direction and $\mathrm{Z}$ lingual direction. Spongy bone was modeled with linear isotropic material. Autodesk Inventor Professional was used for CAD modeling. The division for finite elements was also conduct in this program (fig. 2).

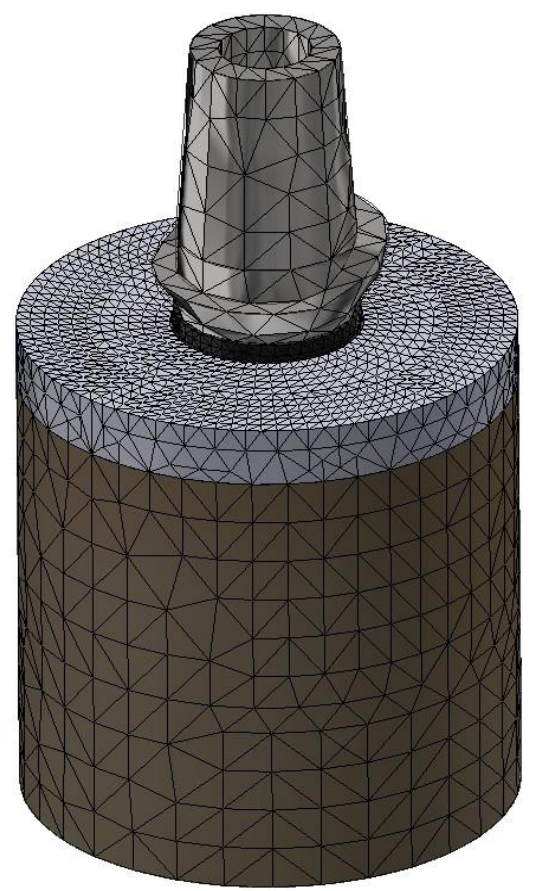

Fig. 2 Simplified models for FEM analysis inside the bone model 
In table 1 are shown mechanical properties of every material used in this analysis. Materials are also assigned to specific component of dental implant system. Stress analysis was conducted with Autodesk Inventor Professional's calculation modulus.

Tab. 1. Mechanical properties [5 - 7]

\begin{tabular}{|c|c|c|c|}
\hline \multicolumn{4}{|c|}{ Mechanical properties } \\
\hline Material & $\begin{array}{c}\text { Assigned } \\
\text { component }\end{array}$ & $\begin{array}{c}\text { Young's modulus } \\
{[\mathbf{G P a}]}\end{array}$ & Poisson ratio \\
\hline $\begin{array}{c}\text { Titanium alloy } \\
\text { (Ti6Al4V) }\end{array}$ & Implant screw & $\mathrm{E}=110$ & $v=0,32$ \\
\hline $\begin{array}{c}\text { Cobalt-chromium } \\
\text { alloy }\end{array}$ & Abutment & $\mathrm{E}=220$ & $v=0,3$ \\
\cline { 2 - 2 } & Connection screw & $\mathrm{E}=2,13$ & $v=0,3$ \\
\hline Cancellous bone & Spongy bone & $\mathrm{Ex}=20,5$ & $v \mathrm{xy}=0,229$ \\
\hline \multicolumn{2}{|c|}{ Cortical bone } & $\mathrm{Ey}=12,5$ & $\mathrm{vyz}=0,433$ \\
& $\mathrm{Ez}=11,3$ & $\mathrm{vxz}=0,236$ \\
\hline
\end{tabular}

The glued contacts between individual implant parts were used. The value of reference force was $100 \mathrm{~N}$ as load quite often mentioned in the literature [5]. Another stress analysis was carried out for $157,5 \mathrm{~N}$ which is the load intensity for posterior teeth number 35 and commonly named "five" [8]. At both analysis, the load was concentrated perpendicularly to upper abutment surface, along Y axis. The bottom part of bone was constrained and fixed.

\section{Results}

Maximum stress distribution according to Huber-Mises hypothesis in the implant screw was noted inside the implant, in the place of contact with connection screw. Maximum value for $100 \mathrm{~N}$ was about $6 \mathrm{MPa}$ and for $157,5 \mathrm{~N}-$ almost $10 \mathrm{MPa}$ (fig. 3 ).
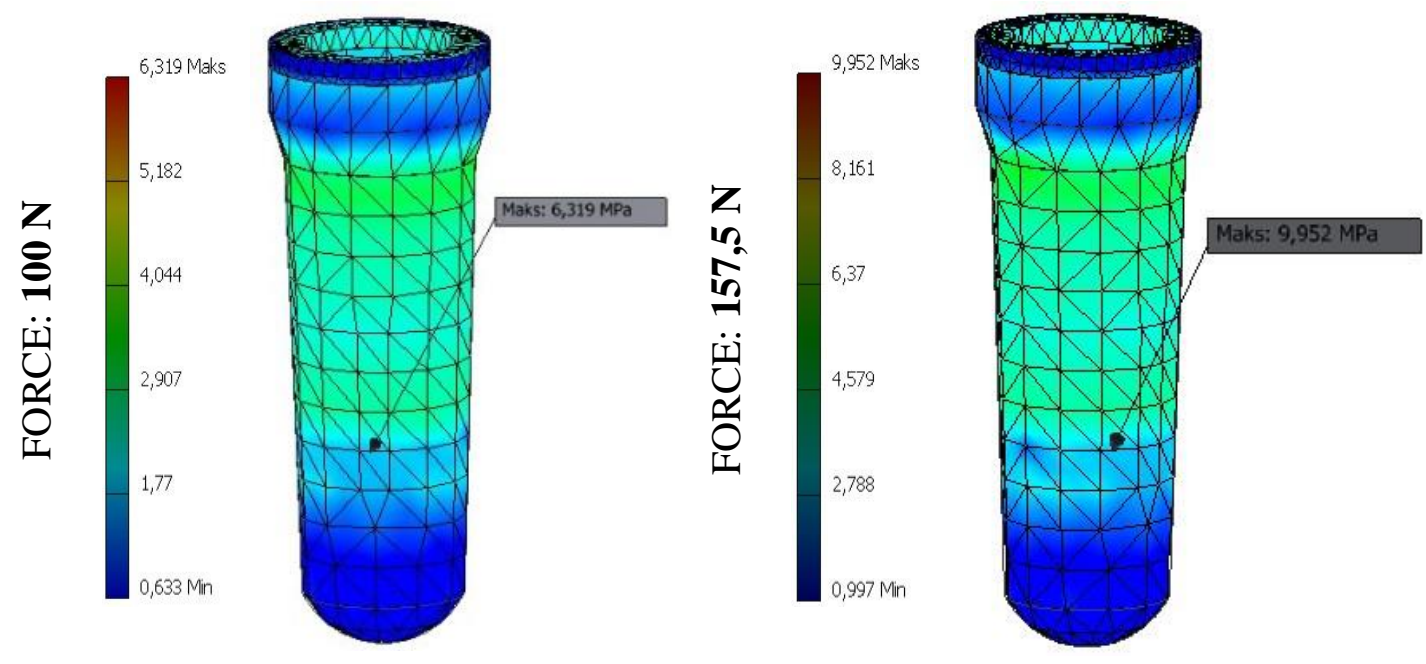

Fig. 3. Maximum stress distribution according to Huber-Mises hypothesis in the implant screw 
Maximum stress distribution according to Huber-Mises hypothesis in the abutment was noted at the upper part of abutment, in the place of contact with glue layer and artificial tooth crown. Maximum value for $100 \mathrm{~N}$ was about $9 \mathrm{MPa}$ and for $157,5 \mathrm{~N}-14,4 \mathrm{MPa}$ (fig. 4).
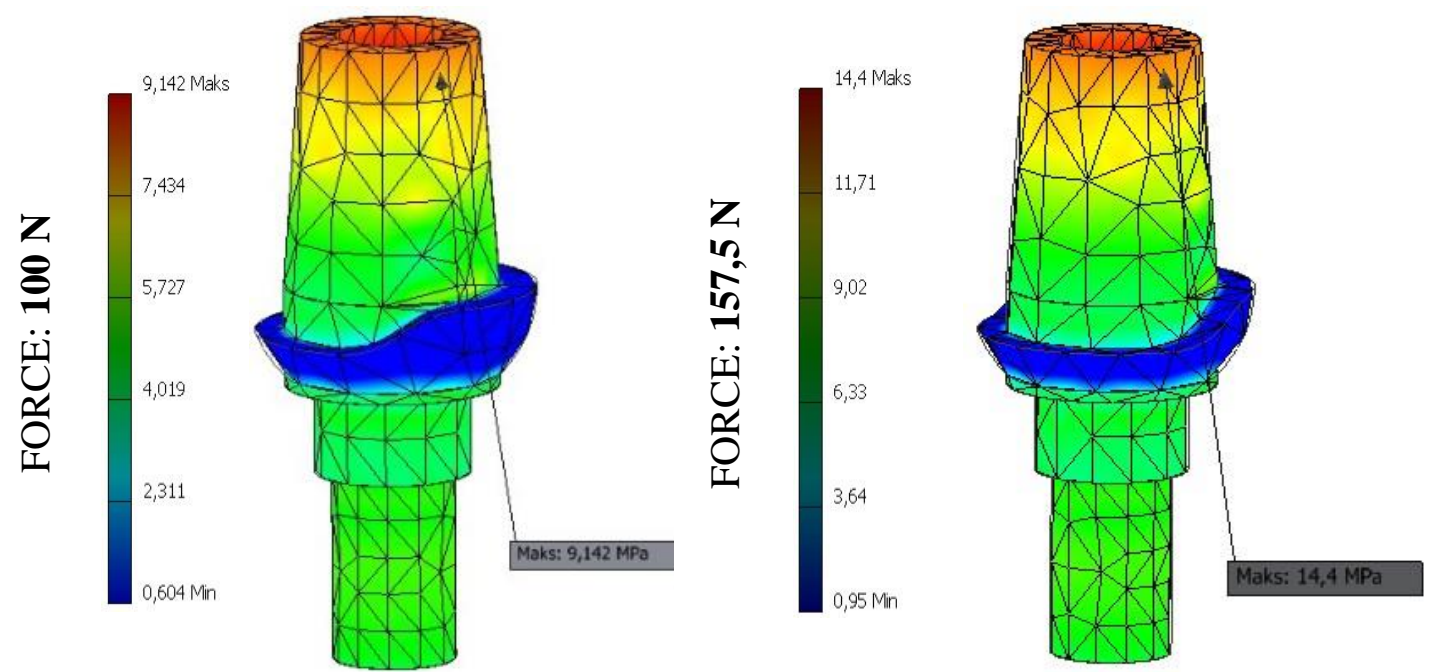

Fig. 4. Maximum stress distribution according to Huber-Mises hypothesis in the abutment

Maximum stress distribution according to Huber-Mises hypothesis in the connection screw was noted at the bottom part of screw, in the place of contact with implant screw. Maximum value for $100 \mathrm{~N}$ was about $11 \mathrm{MPa}$ and for $157,5 \mathrm{~N}$ - almost $18 \mathrm{MPa}$ (fig. 5). $11 \mathrm{MPa}$ and $18 \mathrm{MPa}$ were the maximum values in the whole implant system.
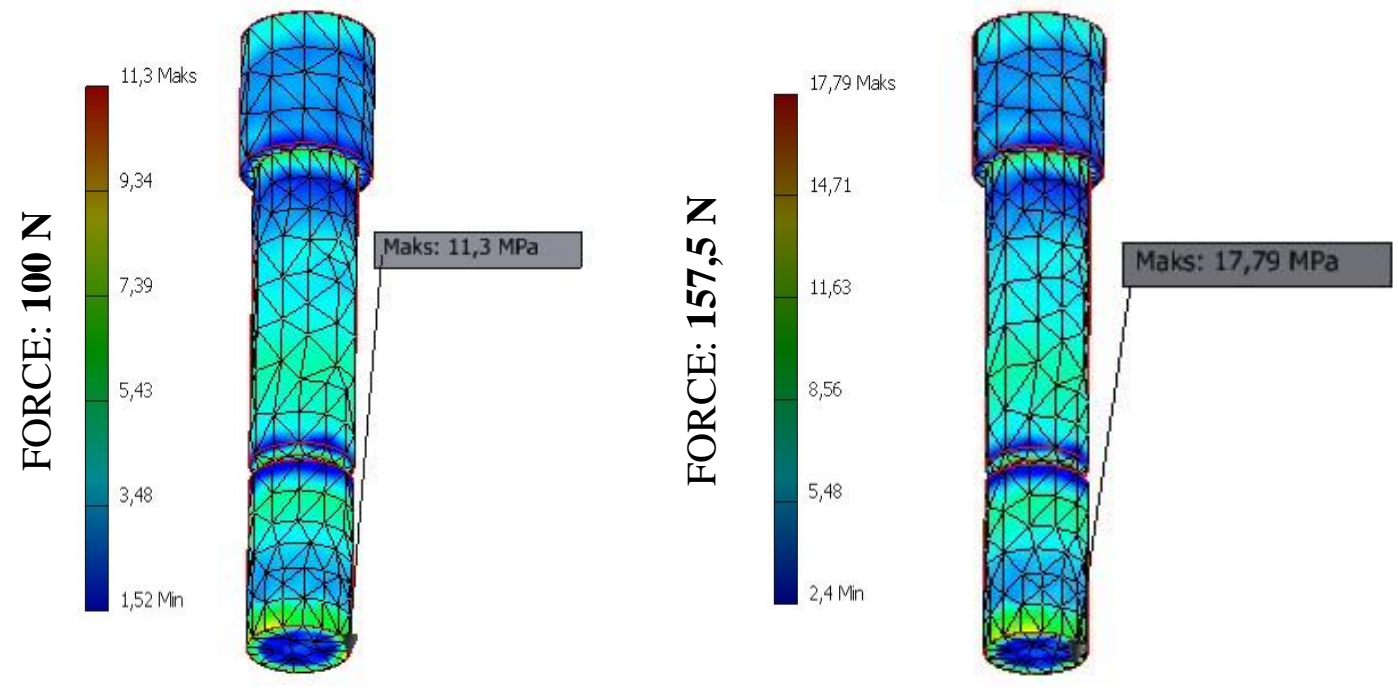

Fig. 5. Maximum stress distribution according to Huber-Mises hypothesis in the connection screw 
Maximum stress distribution according to Huber-Mises hypothesis in the spongy bone was noted in the bottom part of bone, in the place where the constrain was applied. Maximum value for $100 \mathrm{~N}$ was about $6,5 \mathrm{MPa}$ and for $157,5 \mathrm{~N}-$ about $10 \mathrm{MPa}$ (fig. 6).
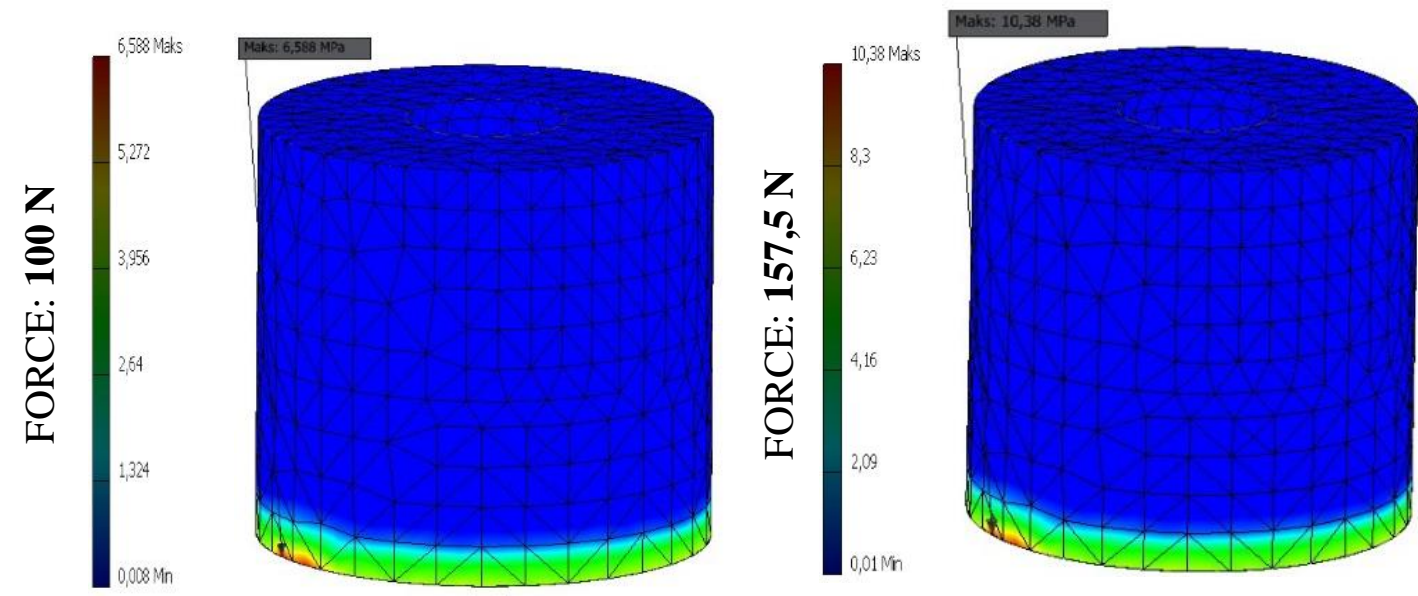

Fig. 6 Maximum stress distribution according to Huber-Mises hypothesis in the spongy bone

Maximum stress distribution according to Huber-Mises hypothesis in the cortical bone was noted inside the aperture, in the place of contact with dental implant screw. Maximum value for $100 \mathrm{~N}$ and $157,5 \mathrm{~N}$ were very insignificantly and reached to 0,000033 for $100 \mathrm{~N}$ and to 0,000052 for $157,5 \mathrm{~N}$ (fig. 7).
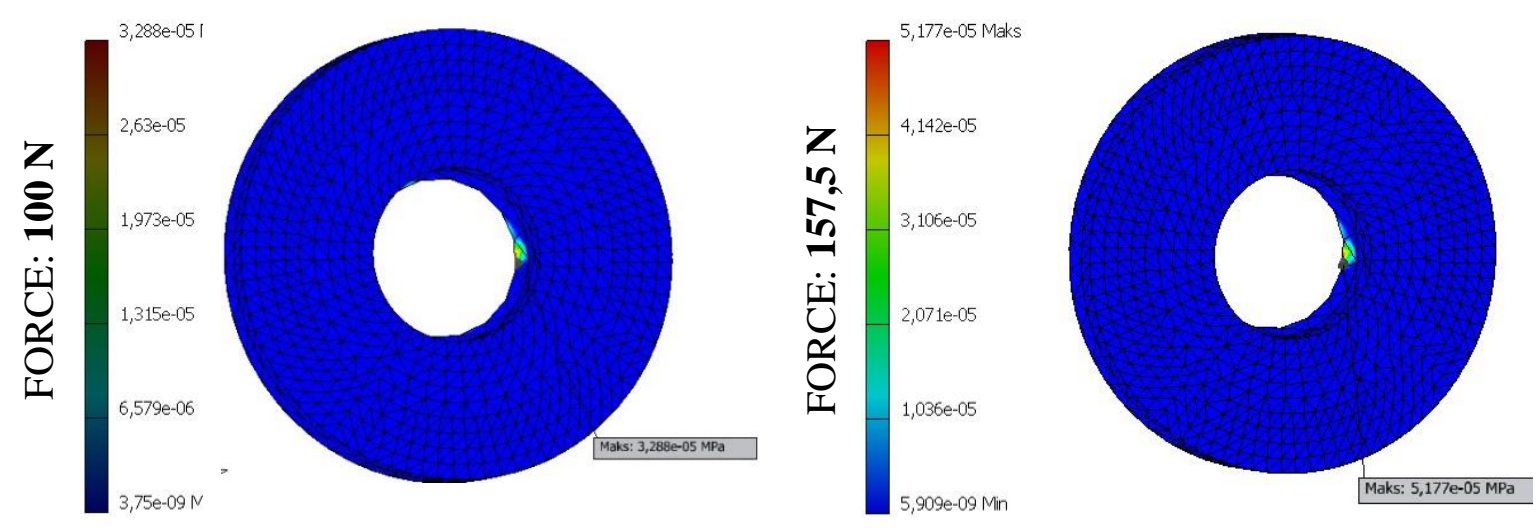

Fig. 7 Maximum stress distribution according to Huber-Mises hypothesis in the cortical bone

\section{CONCLUSION}

The maximum stress distribution according to Huber-Mises hypothesis was noticed in the bottom part of connection screw, in the place of screw contact with implant screw. Maximum stress value were $11,3 \mathrm{MPa}$ for $100 \mathrm{~N}$ and $17,79 \mathrm{MPa}$ for $157,5 \mathrm{~N}$. None of safety ratio was exceeded. The maximum displacement difference value between $100 \mathrm{~N}$ load and 157,5N load was $0,04791 \mathrm{~mm}$. Stress analysis results such as maximum stress value, displacements and deformation value are shown in table 2. 
Tab. 2. Stress analysis results

\begin{tabular}{|c|c|c|c|}
\hline \multicolumn{4}{|c|}{ Maximum results values } \\
\hline Force & $\begin{array}{c}\text { Stress } \\
\text { according to Huber- } \\
\text { Mises hypothesis) }\end{array}$ & Displacements & Deformation \\
\hline $\mathbf{1 0 0 N}$ & $11,3 \mathrm{MPa}$ & $0,08299 \mathrm{~mm}$ & 0,2687 \\
\hline $\mathbf{1 5 7 , 5 N}$ & $17,79 \mathrm{MPa}$ & $0,1309 \mathrm{~mm}$ & 0,4231 \\
\hline
\end{tabular}

Implant construction model was design based on real CAMLOG ${ }^{\circledR}$ implant. Materials used in analysis were the same as CAMLOG ${ }^{\circledR}$. Nowadays, companies more and more often abandon titanium alloy Ti6Al4V. This alloy has vanadium in its composition which could be harmful for human health [9]. In the place of this alloy, more popular becomes the titanium alloy Ti6Al4V ELI with reduced value of vanadium [10]. In terms of material properties, both alloys are not different and their Young's Modulus and Poisson ratio are on the same level [11]. Material changing doesn't affect obtained values, affects only the patient health.

Maximum stress distribution according to Huber-Mises hypothesis was noticed in the connection screw with value almost $18 \mathrm{MPa}$ for load 157,5N. Minimum stress value according to Huber-Mises hypothesis was in cortical bone and was very close to $0 \mathrm{MPa}$ (fig. 8)

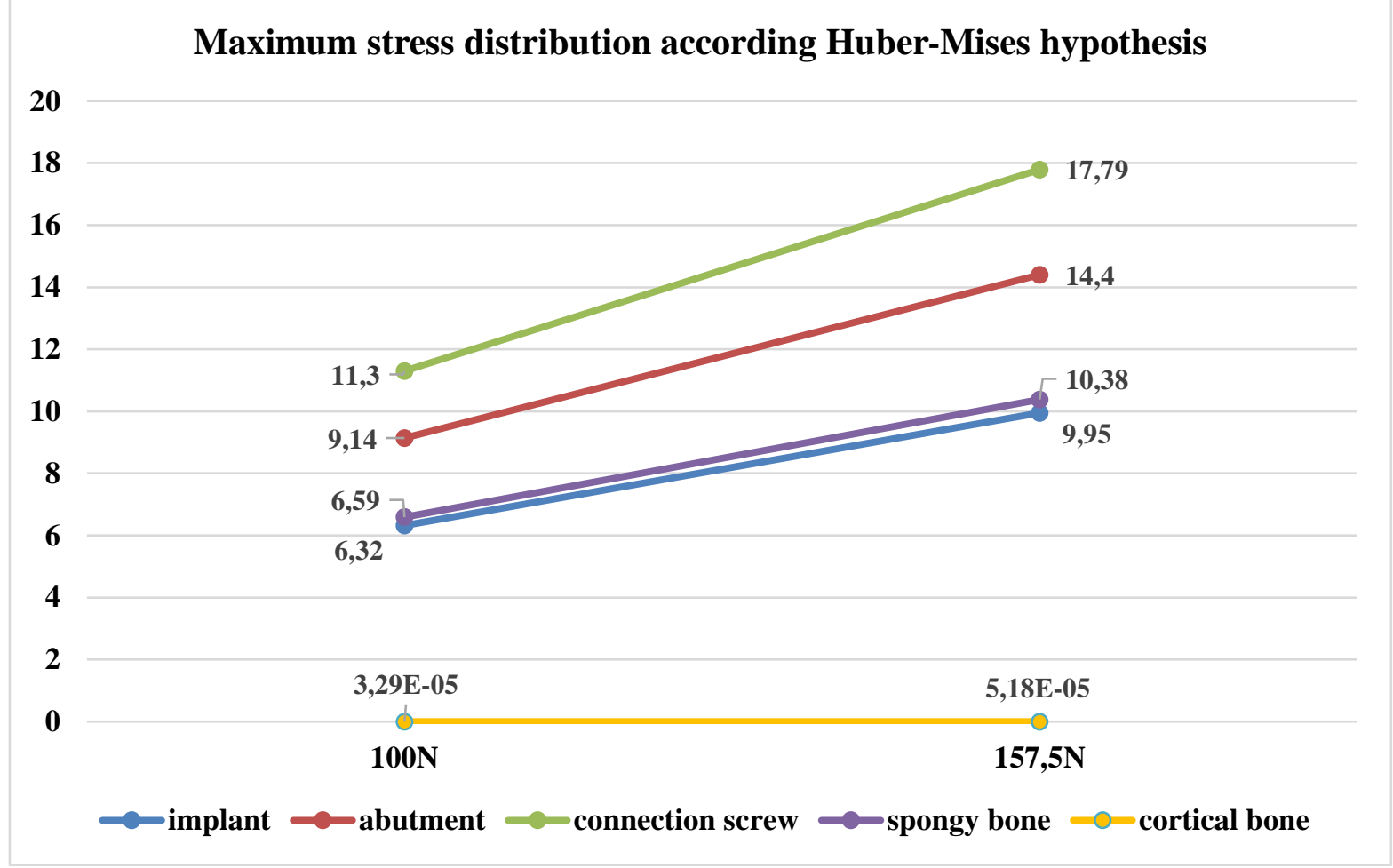

Fig. 8 Maximum stress distribution according to Huber-Mises hypothesis in implant construction 
Every vibration and motion of implant inserted directly into the bone can cause a osseointegration trouble. It is a huge problem for dentists around the world. Interrupted integration of titanium implant and mandible or jaw bone leads to failure of dental implant treatment success. Preclinical computer simulation shows the behavior of implant system and helps match suitable implant diameter and length for individual bone shape.

Influenced force on implant inserted into the bone can cause huge problems connected with correctly osseointegration process. Implant installation conducted incorrectly leads to failure of dental implant treatment. In silico research for individual implant case help healing due to research of basic behavior of planned implant geometry. Results could be helped only when osseointegration process is assumed properly. Only with this condition, the Finite Elements Method could be aid to decide whether selected implant geometry is chosen properly or not and need to be changed.

Assuming that osseointegration process is correct, results suggest that selected implant system components with implant diameter $\varnothing 6 \mathrm{~mm}$ and length $1=16 \mathrm{~mm}$ even under the load impact value $500 \mathrm{~N}$ has high chance for treatment success.

In silico research are more and more popular and more and more often use. FEM is a very versatile tool. Numerical calculation could be helped even in such a widespread field of study - from overhead power lines dynamics [12] to for example, mechanical properties of the bearing part [13]. It is also very interesting and not expensive way for basic assessment of implant treatment success level without integration in patients jaw.

\section{REFERENCES}

[1] A. Koszuta Leczenie protetyczne z zastosowaniem implantów zębowych. Zdrowie Publiczne 2012 (122) 2, 217 - 221.

[2] P-I. Brånemark. Osseointegration Book: from Calvarium to Calcaneus, 1. edit, Berlin; Chicago: Quintessence Publication Corporation, 2006

[3] R. J. Lazzara. Dental implant system design and its potential impact on the establishment and sustainability of aesthetics. Journal of Implant and Reconstructive Dentistry 2012 (1), $1-7$.

[4] M. Kulig. Doświadczalna analiza odkształceń i naprężeń w medycynie. Wydawnictwo Politechniki Krakowskiej, Kraków, 2012.

[5] W. Chladek. Biomechanika Inżynierska Narządu Żucia. Zagadnienia Wybrane. Monography. Gliwice, 2008. ISBN 978-83-7242-622-2

[6] M. Marzec-Gawron, S. Michalska, B. Dejak. Properties of contemporary resin cements and their adhesion to enamel and dentin. Protetyka Stomatologiczna 2012 (3), 173 - 180.

[7] O.Kayabasi, E. Yuzbasioglu, F. Erzincanli. Static, Dynamic and Fatigue Behaviors of Dental Implant Using Finite Elements Method. Advances in Engineering Software 2006 (37), $649-658$.

[8] G. Milewski. Wytrzymałościowe aspekty interakcji biomechanicznej tkanka twarda implant w stomatologii. Kraków. Mechanika, 2002 nr 89., ISSN 0372 - 9486.

[9] J. Marciniak. Biomateriały. Wydawnictwo Politechniki Śląskiej, Gliwice, 2002.

[10] Y. Okazaki, S. Rao, Y. Ito, T. Tateishi. Corrosion resistance, mechanical properties, corrosion fatigue strength and cytocompatibility of new $\mathrm{Ti}$ alloys without $\mathrm{Al}$ and $\mathrm{V}$. Biomaterials 1998 (19), 1197 - 1215. 
[11] ISO 5832-3, Implants for surgery - Wrought titanium-6 aluminium-4 vanadium alloy. ASTM F-136 - Specification for Ti6Al-4V ELI Alloy for Surgical Implant Applications

[12] R. Gogola, J. Murín, J. Hrabovský. Numerical Calculation of Overhead Power Lines Dynamics. Journal of Mechanical Engineering - Strojnicky časopis 2016 (66), No. 2, 13 -22 .

[13] Z. Padovec, R. Sedláček, M. Růžička, P. Růžička. Analysis of Mechanical Properties of the "Bearing" Part Based on Polished Samples. Journal of Mechanical Engineering -, Strojnícky časopis 2017 (67), No. 2, 85 - 90 